\title{
HANDHELD SPEED METERS IN POLAND AND THE STANDARD OF THE HUMAN RIGHTS OF THE DEFENCE
}

\author{
Michat Skwarzyński*
}

\begin{abstract}
This chapter describes the legal basics and the practice of using handheld radar and laser devices in speeding cases. The analysis concerns normative frameworks, unfortunately neglected, as well as indicates problems occurring in cases of offences related to speeding. In judicial practice, radar devices Iskra and lidar devices, colloquially called Ultralyte lasers, are most commonly used .Unfortunately, in judicial practice, the application of the normative framework for the use of lidar and radar equipment is subject to the principle in dubio pro radar.
\end{abstract}

Key words: radar, laser, police, handheld, human rights

\section{INTRODUCTION}

This article presents the legal basis as well as the practice of using radar and lidar handheld devices in cases concerning speeding. The analysis concerns normative frameworks, unfortunately neglected, as well as indicates problems occurring in cases of offences related to speeding. Normative sources in the field of handheld speed meters are basically the same for each of them, some differences occur in the so-called control speed meters - video recorders, which exceeds the scope of this study.

In judicial practice, radar devices Iskra and lidar devices, colloquially called Ultralyte lasers, are most commonly used. They will be used as an

* Department of Human Rights, Institute of Law, Faculty of Law, Canon Law and Administration, email: michalskwarzynski@gmail.com. 
example to indicate a normative framework, but especially police and judicial practice regarding speed meters. This will allow to present actions and omissions of the police, the Central Office of Measures (hereinafter: $\mathrm{COM}$ ) and the Polish legislator.

It should be indicated that the Ultralyte device has been the object of many court rulings in many countries, for instance in cases in the USA: State of Ohio v. Ilya Zhovner; State of Ohio Thomas E. Wilson; State of Ohio v. Adam H. Leonatti, State of Ohio v. Darrell E. Dawson; State of Hawai'i v. John N. Amiral. This indicates that the use of handheld speed meters is a problem faced by courts in different countries.

\section{CONDITIONS FOR THE LAWFUL USE OF SPEED METERS ESTABLISHED IN POLISH LAW}

In order to recreate the normative standard of the use of handheld speed measuring devices on should start with the Act of 11 May 2001 the Law on Measures (hereinafter: LoM) ${ }^{1}$. Four articles are important here: Article 8 par. 1 point $2 \mathrm{LoM}^{2}$; Article 8 a par. $1 \mathrm{LoM}^{3}$ together with Articles 9 LoM and 9a LoM connected with it, defining the implementing regulations. The regulations show that the devices used for measuring speed must pass the legal-metrological inspection and meet the requirements

Journal of Law. of 2016, item 884, consolidated text, as amended.

2 Art. 8. 1. Przyrządy pomiarowe, które mogą być stosowane: (The measuring devices may be used $[\ldots])$

[...]

2. w ochronie bezpieczeństwa i porządku publicznego (to protect safety and public order)

[...], i są określone w przepisach wydanych na podstawie ust. 6, podlegają prawnej kontroli metrologicznej ([...], and defined in regulations adopted on the basis of paragraph 6 , are subject to legal metrological control).

3 Art. 8a. 1. Przyrządy pomiarowe podlegające prawnej kontroli metrologicznej mogą być wprowadzane do obrotu i użytkowania oraz użytkowane tylko wówczas, jeżeli posiadają odpowiednio ważną decyzję zatwierdzenia typu lub ważną legalizację (Measuring devices subject to legal metrological control may be placed on the market, made available for users and used only if their type approval or legalization have been appropriately validated). 
established in the regulations. This applies to two aspects - the first concerns the procedure for obtaining the type approval decision, as well as the procedure for obtaining legalization, and the second one defines the conditions of use of the device during the measurement.

As regards the conditions that the equipment has to meet when transmitting, the Central Office of Measures has not fulfilled its statutory obligations ${ }^{4}$.

In the case of the Iskra device, the research was limited only to the examination of the Iskra Video, with the option of recording, that is why the COM "managed" to fulfil the requirement to indicate the vehicle. The Iskra device itself has never been tested. In the tests performed, the larger vehicle was always the faster one. However, in the case of Ultralyte, the tests were conducted only in the range of 80 meters, although the Type Approval Decision does not determine the maximum measurement distance, and the instructions, depending on the version, specify that the maximum range is from 600 meters to even 1200 meters.

Such a method of research by the COM bears no relation to the rule of law. The tests were performed so as not to detect any irregularities. At no time was the device tested for the possibility of falsification of measurement due to the nature of the device operation, so in the case of the Radar device - Iskra, errors resulting from the beam reflecting from a larger and faster vehicle on the road, reflections from large surfaces such as advertising banners, the impact of power lines and mobile devices on the device. Similarly, it was not checked in Ultralyte whether it is possible to aim the Laser/Lidar device at a vehicle and "hit" the vehicle visible in the sighting scope, and not the vehicle driving past, behind or in front of it (this will be discussed in the next part of the paper). Thus, the research did not verify whether the device is sensitive to "cheating" the operator due to the nature of its operation. They were tested in just one situation that was typical and extremely favourable for the type of device, without any tests in unfavourable conditions. Trials in the road traffic were completely omitted, and the tests were performed at

4 For more cf.: "Wykaz dokumentów", In: Prawo dowodowe w postępowaniach administracyjnych i wykroczeniowych z zakresu w ruchu drogowego, ed. A. Mezglewski, M. Skwarzyński, Lublin, 2018, pp. 155-214. 
an empty airport. Therefore, in practice, the devices arouse such controversy because their suitability for speed measurements in real traffic was not properly checked.

As for the conditions of using the device, the essence of this paper is defined in the Ordinance of the Minister for Economy of 17 February 2014 on the requirements for instruments for measuring the speed of vehicles in road traffic, and the detailed scope of tests and checks performed during legal metrological control of these measuring instruments ${ }^{5}$. In the Ordinance of 2014 , in the inter-temporal provision - \$32, it was indicated that "legal provisions currently in force apply to legal metrological control of instruments in cases initiated and not completed before the Ordinance enters into force". This means that the conditions established in this Ordinance are to be met by all devices used during its validity. The application of previous provisions has been limited solely to proceedings regarding "legal metrological control". According to $\$ 1$ of the Ordinance of 2014, "\$1 Point 1 of the Ordinance specifies:

1) requirements in the scope of construction, workmanship, materials and metrological characteristics, which should correspond to the following instruments for measuring the speed of vehicles in traffic: a) radar, b) laser, c) control speed meters;

2) requirements regarding the conditions of proper use of the instruments referred to in point 1;

3) detailed scope of examinations and checks performed during legal metrological control of instruments referred to in point 1;

4) the scope of information that should be contained in the instruction manual for the instruments referred to in point 1.

Point 2. Whenever the Ordinance refers to a device without further specification, it should be understood as each of the instruments referred to in $\$ 1$ Point 1."

This means that the inter-temporal provision specified in $\$ 32$ of the Ordinance of 2014 refers to the application of previous regulations only in the scope of $\$ 1$ point 1 item 3 of the Ordinance of 2014 and Chapter 5 of the Ordinance, i.e. $\$ 25-31$, while the provisions that apply in the remaining scope are the ones that are currently in force.

5 Journal of Law of 2014, item 281, hereinafter: Ordinance of 2014. 
Therefore, for all devices the requirement provided in $\$ 5$ of the Ordinance of 2014 applies, which specifies that: "\$5. 1. The construction and workmanship of the device should provide an indication of the vehicle whose speed has been measured. 2. The requirement referred to in point 1 should also be met if the vehicle speed is measured in a group of vehicles, or if the vehicle passes, bypasses or overtakes another vehicle. 3. In the event of failure to comply with the requirement referred to in point 1, the device should not indicate and record the result of the speed measurement't.

The interpretation of this provision raises doubts, although according to the author they are the result of the application of a principle which is unconstitutional and contrary to human rights, i.e. in dubio pro radar. It is semantically obvious that the wording: "Construction and workmanship [...] should provide an indication of the vehicle" refer to the device, not to its operator. That is, the device is to provide identification, not a policeman or device operator. This is in accordance with the teleological interpretation, where the legislator increases and not lowers the standards of devices along with the development of technology. There are devices on the market that identify the vehicle by, for instance, making a recording, taking a photo, etc., whereas the COM has made its own interpretation, recognizing that this standard obliges the operator to be able to identify the vehicle ${ }^{7}$.

6 A similar provision could be found in the previous Ordinance, vide: $\$ 10$ ust. 1 pkt 1 Rozporządzenia Ministra Gospodarki z dnia 9 listopada 2007 r. „W sprawie wymagań, którym powinny odpowiadać przyrządy do pomiaru prędkości pojazdów w ruchu drogowym, oraz szczegółowego zakresu badań i sprawdzeń wykonywanych podczas prawnej kontroli metrologicznej tych przyrządów pomiarowych" (\$10 section 1 point 1 of the Ordinance of the Minister of Economy of 9 November 2007 "On the requirements to be met by instruments for measuring the speed of vehicles in road traffic, and the detailed scope of tests and checks performed during legal metrological control of these instruments"), Journal of Law of 2007, No. 225, item 1663.

For more cf.: M. Skwarzyński "Znaczenie dowodowe prawnometrologicznych ręcznych urządzeń radarowych i lidarowych w sprawach o przekroczenie prędkości”, In: Prawo dowodowe w postępowaniach administracyjnych i wykroczeniowych z zakresu w ruchu drogowego, ed. A. Mezglewski, M. Skwarzyński, Lublin, 2018, pp. 93-110. 


\section{NORMATIVE SOURCES OF THE HUMAN RIGHTS \\ OF THE DEFENCE BY CALLING INTO QUESTION THE RESULT \\ OF SPEED MEASUREMENT}

One should begin with presenting the normative framework of the the rights of the defence. It should be emphasized that human rights have the task to, more or less successfully, express normatively the inherent human dignity $^{8}$, which is the source of all rights of the individual. Normatively human rights are personal rights, so this is the sphere in which a person can exercise his own: freedom as a sphere of opportunity, entitlement, and/ or competence ${ }^{9}$, but in this case the state must behave actively and provide legal protection by creating standards in positive law. Therefore, a human right is a kind of freedom, power or competence and an individual wishing to pursue it has the right to demand from the state protection in its exercise that the state must provide. A specific feature of human rights is that the obligation to respect human rights rests on the state first. The assumption is that through this system protection against the adverse actions of the state apparatus is to be provided to the individual, and the state has the obligation to protect the rights and freedoms of individuals. Thus, if one assumes that a given freedom, understood as the sphere of possibility of conduct, entitlement, and/or competence is a human right, then the state has the obligation to create a system of positive law in which the exercise of individual rights arising from this human right is possible. Every human right consists of a bundle of specific entitlements that have more or less

8 For more on personal and personality dignity see: K. Orzeszyna, "Godność ludzka podstawą praw człowieka”, In: Człowiek i jego prawa i odpowiedzialność, ed. R. Tabaszewski, Lublin. 2103, p. 23 ff.; J. Krukowski, "Godność człowieka podstawą konstytucyjnego katalogu praw i wolności jednostki”, In: Podstawowe prawa jednostki i ich sądowa ochrona, ed. L. Wiśniewski, Warszawa, 1997, 39-42; W. Jedlecka, J. Policiewicz, "Pojęcie godności na tle Konstytucji RP”, In: Z zagadnień teorii i filozofii prawa. Konstytucja, ed. A. Bator, Wrocław, 1999, p. 146; J. Zajadło, "Godność jednostki w aktach międzynarodowej ochrony praw człowieka”, Ruch Prawniczy, Ekonomiczny i Socjologiczny 2(1989): 111; K. Complak, "Uwagi o godności człowieka oraz jej ochrona w świetle nowej konstytucji”, Przegląd Sejmowy 5(1998): 42 ff.

9 P. Tuleja, Stosowanie Konstytucji RP w świetle zasady jej nadrzędności (wybrane problemy), Kraków, 2003, p. 135, similarly A. Michalska, Podstawowe prawa człowieka w prawie wewnętrznym a pakty praw człowieka, Warszawa, 1976, p. 62. 
specified normative content. This is particularly visible in the case of the rights of the defence.

It should be further indicated that this human right is the right of the first generation. Generations of human rights were first observed and described by Karel Vasak in the seventies of the twentieth century. ${ }^{10}$ According to him, each of the rights, regardless of generation, is the same in rank and value ${ }^{11}$, although the doctrine assumes a different scope of protection of human rights in a specific case depending on the generation in which the right operates. The first generation of human rights contains personal and political rights and freedoms, and this group includes human right to a fair trial and human rights of the defence. This generation is the main core of protection of human rights. They have a precise content and they are binding. The second generation are social, cultural and economic rights and freedoms, whose scope of specification in conventions depends on the stage of economic and cultural development of a given society. In consequence the rights of the second generation are protected when the development of a given society permits, but only to the extent possible at a given stage of development. These rights are not protected in absolute terms, like first generation rights. The third, currently shaped generation

10 For more cf.: K. Vasak, "A 30-year struggle - The sustained efforts to give force of law to the Universal Declaration of Human Rights", The UNESCO Courier: a window open on the world, 11(1977): 29, 32; K. Vasak, "Human Rights as a Legal Reality", In: The International dimensions of human rights, ed. K. Vasak, UNESCO, Paris, Westport, 1982, pp. 3-9; K. Vasek, "Part II: International Institutions for the protection and promotion of human rights. The Distinguishing Criteria of Institutions", In: Ibidem, pp. 215-230; K. Vasak, "Sub-part II: Regional Institutions for the promotion and protection of human rights. Introduction", In: Ibidem, pp. 451-456; K. Vasak, "Sub-part II: Regional Institutions for the promotion and protection of human rights. The Council of Europe", In: Ibidem, pp. 457-542; M. Piechowiak, Filozofia praw człowieka, Lublin, 1999, pp. 74-76; S. Ruchała, "Współczesne filozoficzne spory o ugruntowanie praw człowieka, Rozprawa doktorska napisana pod kierunkiem prof. dra hab. Kazimierza Ślęczki”, Katowice 2006 r. Uniwersytet Śląski w Katowicach Wydział Nauk Społecznych Instytut Filozofii: 93-129, 3 May 2011, http://www.sbc.org.pl/Content/4445/doktorat2680.pdf; B. Banaszak, "Ogólne wiadomości o prawach człowieka. Geneza praw człowieka i ewolucja systemów ich ochrony", In: Prawa i wolności obywatelskie w Konstytucji RP, ed. B. Banaszak, A. Preisner, Warszawa, 2002, p. 29; P. Kowalski, "Nowe prawa człowieka perspektywy i zagrożenia”, RPEiS, 2(1988): $58 \mathrm{ff}$.

${ }_{11}$ Cf.: S. Ruchała, op. cit.: p. 93. 
of human rights, are rights and freedoms to peace, self-determination, environment and development. As rightly emphasized in the doctrine "third generation rights (...) are mainly collective and postulate" 12 , these are "collective rights, solidarity rights"13. Since the human right to a fair trial and defence is the first generation right, then the state is obliged to actively ensure its implementation, also by way of creating a legal system where the right can be exercised - in which it will be possible to use a bundle of rights arising from the rights of the defence.

The main normative source in the universal system of human rights is the International Covenant on Civil and Political Rights (hereinafter: ICCPR $)^{14}$. Article 14 paragraph 3 letter e ICCPR contains the regulation concerning a fair trial, including the human rights of the defence ${ }^{15}$.

In turn, in international European law two key sources can be found of the right to a fair trial and the rights of the defence. In the Convention for the Protection of Human Rights and Fundamental Freedoms of 4 November 1950 (hereinafter: ECHR) ${ }^{16}$, Article 6 paragraph 3 letter d ECHR ${ }^{17}$ contains the regulation on human rights to a fair trial and the rights of the defence. The Charter of Fundamental Rights (hereinafter: CFR) ${ }^{18}$ is not

12 Cf.: A. Bałaban, Polskie problemy ustrojowe. Konstytucja, źródła prawa, samorząd terytorialny, prawa człowieka, Kraków, 2003, p. 143.

13 Cf.: P. Sendecki, "O niedosycie refleksji nad prawami człowieka w praktyce ich stosowania”, In: Państwo. Prawo. Myśl Prawnicza. Prace dedykowane profesorowi Grzegorzowi Leopoldowi Seidlerowi w dziewięćdziesiątą rocznicę urodzin, ed. A. Korobowicz, L. Leszczyński, A. Pieniążek, M. Stefaniuk, Lublin, 2003, pp. 81 - 92.

14 Open for signature in New York on 19 December 1966. Annex to Journal of Law 1977; No. 38, item 167.

15 3. In the determination of any criminal charge against him, everyone shall be entitled to the following minimum guarantees, in full equality: (e) To examine, or have examined, the witnesses against him and to obtain the attendance and examination of witnesses on his behalf under the same conditions as witnesses against him.

16 Journal of Law of 1993, No. 61, item 284, as amended.

17 3. In the determination of any criminal charge against him, everyone shall be entitled to the following minimum guarantees, in full equality:(d) To be tried in his presence, and to defend himself in person or through legal assistance of his own choosing; to be informed, if he does not have legal assistance, of this right; and to have legal assistance assigned to him, in any case where the interests of justice so require, and without payment by him in any such case if he does not have sufficient means to pay for it.

18 Of 7 December 2000, OJ EU of 2010, C. 83, p. 389. 
a direct source of law in the Polish legal order, because according to Article 1 point 1 of the "British Protocol" attached to the Treaty of Lisbon, referring to Poland and the United Kingdom, one cannot effectively refer to its content ${ }^{19}$, but "the standards contained in the CFR in Poland are valid either as constitutional standards or as international standards that are binding for Poland"20. In Article 48 paragraph 2 CFR it was directly indicated that "Respect for the rights of the defence of anyone who has been charged shall be guaranteed", whereas Article 47 CFR defines the right to use the assistance of a lawyer.

On the basis of these sources of human rights of the defence, it is important to emphasize that the standards resulting from these norms, according to their content, concern "the legitimacy of accusation in criminal matters" - Article 14 paragraph $1 \mathrm{ICCPR}$ or "justifiability of any accusation in a criminal case" - Article 6 paragraph 1 ECHR. Literature has already pointed to the inconsistency of the European Court of Human Rights whether these standards apply to a case of offence and whether such a matter is covered by the human right to a fair trial. In other words, whether the proceedings and trial in offence case are a criminal matter according to the standards set by the Strasbourg Court. ${ }^{21}$ Nevertheless, these standards allow to determine to what scope of minimum rights a person accused is entitled in criminal cases. One of the rights arising from their bundle included in the right to a fair trial is the substantive and formal right to defence, that is, the right to defend oneself and through a professional advocate - a lawyer, even if the person cannot afford a legal counsel of choice. On the other hand, from he rights of the defence follows the right

19 For more cf.: A. Wyrozumska, "Ochrona praw podstawowych w Unii Europejskiej”, In: Obywatel Unii. Tom VI Traktat z Lizbony, ed. I. Skomerska - Muchowska, A. Wyrozumska, Warszawa, 2010, p. 219 ff. and K. Kowalik-Bańczyk, "Konsekwencje przyjęcia protokołu polsko-brytyjskiego dotyczące stosowania Karty Praw Podstawowych", In: Karta Praw Podstawowych w europejskim i krajowym porządku prawnym, ed. A. Wróbel, Warszawa, 2009, pp. 136 - 138.

20 R. Wieruszewski, "Postanowienia Karty Praw Podstawowych w świetle wiążących Polskę umów międzynarodowych i postanowień Konstytucji RP z 1997 r.”, In: Ochrona praw podstawowych w Unii Europejskiej, ed. J. Barcz), Warszawa, 2008, p. 143.

${ }_{21}$ M. Skwarzyński, "Prawo człowieka do obrony a postępowanie wykroczeniowe w Polsce”, In: Straż gminna jako organ kontroli ruchu drogowego, ed. A. Mezglewski, Lublin, 2014, pp. 112-117, $120 \mathrm{ff}$. 
to inspect evidence of prosecution. The verba legis of international law only concerns examining or having examined prosecution witnesses and an adequate examination of defence witnesses. However, the case law shows that these standards concern all evidence in the case.

It was rightly indicated in the doctrine that the Strasbourg Court noted that "when assessing whether the procedure as a whole was reliable, it should, inter alia, be determined whether the rights of the defence have been respected, including examining in particular whether the accused could challenge the authenticity of the evidence and oppose using it in the trial. In addition, when assessing the quality of the evidence, it must be established whether the circumstances of obtaining it did not give rise to doubts as to its credibility or accuracy" and that "it is assumed that every evidence must be carried out in the presence of the accused during a public hearing in order to allow the opposing party to present their arguments" 22 . This means that evidence in the form of a speed measurement result can be questioned on the basis of the credibility of the evidence.

Importantly, neither international law on human rights nor the Constitution creates human rights and individual rights, but only expresses them normatively. They result from the inherent human dignity and positive law only confirms their existence. This is important because the exact normative expression and the effects of linguistic interpretation can be misleading. Semantically, the rights of the defence can receive various names, which does not change the fact that it is about defending the same component of human dignity, so the same human right, regardless of the words used. Thus, protection of the rights of the defence on the constitutional ground against proceedings concerning offences will include the protection of partial rights to verify evidence of prosecution.

In the national system of human rights, the rights of the defence were explicitly stated in the Constitution of the Republic of Poland of 2 April 1997 (hereinafter: Polish Constitution) ${ }^{23}$. They are defined in Article 42

22 M. A. Nowicki, "Komentarz do art. 6 Konwencji o ochronie praw człowieka i podstawowych wolności”, In: Wokół Konwencji Europejskiej. Komentarz do Europejskiej Konwencji Praw Człowieka, Warszawa: System Informacji Prawnej LEX, 2017, and especially the case law cited in footnote 1609.

23 Journal of Law of 1997, No. 78, item 483. 
paragraph 2 of the Constitution of the Republic of Poland, which states that "Anyone against whom criminal proceedings have been brought shall have the right to defence at all stages of such proceedings. He may, in particular, choose counsel or avail himself - in accordance with principles specified by statute - of counsel appointed by the court." This content is similar to the one defined in the Charter of Fundamental Rights, and the design of the provision is different from that of the human right to a fair trial contained in Article 14 ICCPR and Article 6 ECHR. However, this does not change the fact that on the constitutional ground a person charged with an offence $^{24}$ is entitled to this right, and it includes the protection of the right to verify evidence of accusation.

\section{THE JURISPRUDENCE OF POLISH COURTS ON SPEED METERS THAT IMPLEMENTS THE STANDARD OF THE HUMAN RIGHTS}

\section{OF THE DEFENCE}

The views that implement the human rights of the defence, which aim to undermine the result of speed measurement, are more and more frequently found in the jurisprudence of Polish courts.

First of all, it is about the lack of a system of appropriate training for police officers who cannot use the device properly and cannot reject erroneous measurements. Training usually consists in showing the device, showing how measurement is made and getting acquainted with the instructions. Nobody trains police officers how to recognize incorrect measurements and how to reject them. What is more, police officers are misled into thinking that if the device shows a given result, it is correct. One should indicate here the Judgement of the District Court in Zamość in case II Ka 779/13, which states explicitly: "As a side note, it should be mentioned that the outcome of this case, as well as similar ones, undermines the trust in the reliability of measurement activities of traffic control services, which, according to the opinion of an expert in the field of measuring

24 M. Skwarzyński, "Prawo człowieka do obrony a postępowanie wykroczeniowe w Polsce”, In: Straż gminna jako organ kontroli ruchu drogowego, ed. A. Mezglewski, Lublin, 2014, pp. 117-121. 
technology, due to the lack of specialised training, unintentionally also mislead the judicial authorities as to the reliability of their measurements. Therefore, it is necessary to postulate the development of reliable measurement procedures for road traffic services, as well as reliable documentation of parameters of exceeded speed, including the time of measurement and the distance from which the measurements were made. On the other hand, the courts, while recognizing such cases, should show increased criticism regarding the evidence presented to them by the Police." 25 Training in police schools is insufficient because, as a rule, measuring devices take one day of training, without learning the practical use of each of them.

In addition, according to $\$ 23$ of the Ordinance of 2014 " $\$ 23$. 1. The device should be used under the rated operating conditions in a manner consistent with the operating instructions and the Type Approval Decision. 2. The device should be installed in a manner consistent with the instruction manual." The necessary elements of the instructions are mentioned in $\$ 24$ of the Ordinance of 2014. The problem is that most operators - policemen, do not know the Type Approval Decision, and they only determine the conditions of use of the device. The Type Approval Decision is confused with the decision on primary and secondary legalization. Type Approval Decision is a decision regarding the terms of use of a given type of device, e.g. Ultralyte or Iskra. This applies to the Type of devices, i.e. all devices of this model. In contrast, legalization concerns the verification of a specific device with a specific number whether it meets the requirements of: laws, ordinances and precisely the Type Approval Decision. Therefore, measurements are made against the conditions set by the COM in this decision, and very often the conditions provided in the instructions are contrary to the Act, Regulations and Type Approval Decision.

What is more, it is also problematic to use the Instructions provided by the manufacturer of the device. There different types of instruction manuals in circulation, i.e. short, marketing and other instructions that have a different content from that which the COM investigated when issuing the Type Approval Decision or when legalizing. Therefore, they may contain other provisions than the instructions that the Office controlled.

25 Cf.: The Judgement in the part on the Selection of Sources. 
Secondly, it is about the identification of the vehicle by the device itself. Experts and courts often ignore this requirement, although it is rational, because the device itself can measure the speed of a vehicle other than the one the policeman wanted to measure. The view that the device must meet the identification requirement can be found in the case law regarding handheld devices Iskra and Ultralyte, vide: Judgement of the District Court in Myślibórz of 3 July 2016 in case II in 691/15 regarding Iskra, where oral justification confirms this ${ }^{26}$; Decision of the District Court in Kozienice of 17 December 2014 in case VII Ko 1203/14 regarding Iskra; Judgement of the District Court in Trzcianka of 4 September 2013, case II W 66/13 regarding Iskra; or of the District Court in Łęczyca, case II In 1680/15 regarding Ultralyte, where the advocate indicated that, among others, this allegation showed that the device cannot provide evidence in the case. Ultralyte and Iskra do not identify the vehicle, the policeman does it by looking through the sighting scope in the case of Ultralyte, and in the case of Iskra, by aiming the device at the approaching vehicle. The situation is similar with other handheld measuring devices, where the policeman decides "at a glance" that the measured car is the intended one. Such action is contrary to the verba legis of the Ordinance. A similar position was taken by the Ministry of Justice ${ }^{27}$.

The most convincing in this matter is the Judgement of the District Court in Gliwice of 23 October 2018, case VI Ka 695/18. This court had to deal with the alleged speed measurement performed by police officers who were later arrested on suspicion of accepting bribes from drivers. The actions of these policemen also consisted in assigning the measurement of certain vehicles to drivers of other vehicles, or generating the measurement artificially, because the drivers had not seen the device in the hands of the policemen, and the officers did not even want to show the results of the measurement. This example shows why the identification requirement is necessary. The District Court in Gliwice stated that the inter-temporal provision of $\$ 32$ of the Ordinance of 2014 imposes on the device the obligation to identify the vehicle on its own.

26 Published on BigosTV and the YouTube Channel of Emil Rau: https://www.youtube.com/watch? $=16$ usKevElgQ.

27 Cf.: Reply to the Interpellation in the part on Selection of Sources. 
Another example is the Judgement of the District Court in Ostrołęka of 13 September 2018, case II Ka 287/18, which indicated that the Ultralyte device must identify the vehicle by itself, because the measuring beam may cover more than one vehicle and there may be a slip effect of the beam.

\section{SUMMARY}

Unfortunately, in judicial practice, the application of the normative framework for the use of lidar and radar equipment is subject to the principle in dubio pro radar. This applies to cases where there are no prepared legal counsels or people exercising social control of the courts and having knowledge of the work of radar equipment. The courts presume the credibility of measuring devices, the correctness of measurement, and the qualifications of a policeman.

It should be indicated that the normative regulation of the European Convention for the Protection of Human Rights and Fundamental Freedoms and the Polish Constitution guarantees the possibility of verifying evidence of prosecution, also if it is the result of speed measurement. At the same time, the Constitution provides a more certain and definitely greater guarantee of protection of the the defendant's right to defence in offence proceedings. The main reason for this state of affairs is the content of the Polish Constitution, where verba legis the right to defence and the presumption of innocence are defined as rights that apply to everyone, so also a person charged with an offence. A criminal case is recognised similarly, and the Constitutional Court also considers a case of an offence to be a criminal case. It should be expected that the case regarding doubtful speed meters will be in the Court's interest and that it will focus on the quality of the equipment used and the practice of the legislator, the COM and the police.

The more and more frequent judgements of common courts give hope, as there are judges who do not want to hide behind the screen of the "decision on legalization" or "expert opinion", but treat the result of speed measurement as any evidence in the case and apply the principle of resolving doubts regarding measurement in favour of the accused, and they pursue the purpose of justice and do not convict a person who has 
not exceeded speed. The inquisitiveness of these courts and the possibility of undermining biased expert opinions "for the thesis" will allow to change over time the practice of using such devices.

\section{REFERENCES}

Bałaban A., 2003, Polskie problemy ustrojowe. Konstytucja, źródła prawa, samorząd terytorialny, prawa człowieka, Kraków.

Banaszak B., 2002, "Ogólne wiadomości o prawach człowieka. Geneza praw człowieka i ewolucja systemów ich ochrony”, In: Prawa i wolności obywatelskie w Konstytucji RP, ed. B. Banaszak, A. Preisner, Warszawa.

Complak K., 1998, “Uwagi o godności człowieka oraz jej ochrona w świetle nowej konstytucji”, Przegląd Sejmowy 5.

Krukowski J., 1997, "Godność człowieka podstawą konstytucyjnego katalogu praw i wolności jednostki”, In: Podstawowe prawa jednostki i ich sądowa ochrona, ed. L. Wiśniewski, Warszawa.

Jedlecka W., Policiewicz J., 1999, “Pojęcie godności na tle Konstytucji RP”, In: $\mathrm{Z}$ zagadnień teorii i filozofii prawa. Konstytucja, ed. A. Bator, Wrocław.

Kowalik-Bańczyk K., 20009, "Konsekwencje przyjęcia protokołu polsko-brytyjskiego dotyczące stosowania Karty Praw Podstawowych”, In: Karta Praw Podstawowych w europejskim i krajowym porządku prawnym, ed. A. Wróbel, Warszawa.

Kowalski P., 1988, "Nowe prawa człowieka perspektywy i zagrożenia”, RPEiS, 2(1988);

Michalska A., 1976, Podstawowe prawa człowieka w prawie wewnętrznym a pakty praw człowieka, Warszawa.

Mezglewski A., Skwarzyński M., 2018, Prawo dowodowe w postępowaniach administracyjnych i wykroczeniowych z zakresu w ruchu drogowego, Lublin.

Nowicki M. A., 2017, "Komentarz do art. 6 Konwencji o ochronie praw człowieka i podstawowych wolności”, In: Wokół Konwencji Europejskiej. Komentarz do Europejskiej Konwencji Praw Człowieka, Warszawa: System Informacji Prawnej LEX.

Orzeszyna K., 2013, "Godność ludzka podstawą praw człowieka”, In: Człowiek i jego prawa i odpowiedzialność, ed. R. Tabaszewski, Lublin.

Piechowiak M., 1999, Filozofia praw człowieka, Lublin.

Ruchała S., 2011, "Współczesne filozoficzne spory o ugruntowanie praw człowieka, Rozprawa doktorska napisana pod kierunkiem prof. dra hab. Kazimierza 
Ślęczki”, Katowice 2006 r. Uniwersytet Śląski w Katowicach Wydział Nauk Społecznych Instytut Filozofii, 3 May 2011, http://www.sbc.org.pl/Content/4445/doktorat2680.pdf.

Sendecki P., 2003, "O niedosycie refleksji nad prawami człowieka w praktyce ich stosowania”, In: Państwo. Prawo. Myśl Prawnicza. Prace dedykowane profesorowi Grzegorzowi Leopoldowi Seidlerowi w dziewięćdziesiątą rocznicę urodzin, ed. A. Korobowicz, L. Leszczyński, A. Pieniążek, M. Stefaniuk, Lublin. Skwarzyński M., 2014, "Prawo człowieka do obrony a postępowanie wykroczeniowe w Polsce”, In: Straż gminna jako organ kontroli ruchu drogowego, ed. A. Mezglewski, Lublin.

Skwarzyński M. 2018, "Znaczenie dowodowe prawnometrologicznych ręcznych urządzeń radarowych i lidarowych w sprawach o przekroczenie prędkości”, In: Prawo dowodowe w postępowaniach administracyjnych i wykroczeniowych z zakresu w ruchu drogowego, ed. A. Mezglewski, M. Skwarzyński, Lublin.

Tuleja P., 2003, Stosowanie Konstytucji RP w świetle zasady jej nadrzędności (wybrane problemy), Kraków.

Vasak K., 1977, "A 30-year struggle - The sustained efforts to give force of law to the Universal Declaration of Human Rights", The UNESCO Courier: a window open on the world, 11(1977).

Vasak K., 1982, "Human Rights as a Legal Reality", In: The International dimensions of human rights, ed. K. Vasak, UNESCO, Paris, Westport.

Vasek K., 1982, "Part II: International Institutions for the protection and promotion of human rights. The Distinguishing Criteria of Institutions", In: The International dimensions of human rights, ed. K. Vasak, UNESCO, Paris, Westport.

Vasak K., 1982, "Sub-part II: Regional Institutions for the promotion and protection of human rights. Introduction", In: The International dimensions of human rights, ed. K. Vasak, UNESCO, Paris, Westport.

Vasak K., 1982, "Sub-part II: Regional Institutions for the promotion and protection of human rights. The Council of Europe", In: The International dimensions of human rights, ed. K. Vasak, UNESCO, Paris, Westport.

Wieruszewski R., 2008, "Postanowienia Karty Praw Podstawowych w świetle wiążących Polskę umów międzynarodowych i postanowień Konstytucji RP z 1997 r.", In: Ochrona praw podstawowych w Unii Europejskiej, ed. J. Barcz), Warszawa.

Wyrozumska A., 2010, “Ochrona praw podstawowych w Unii Europejskiej”, In: Obywatel Unii. Tom VI Traktat z Lizbony, ed. I. Skomerska - Muchowska, A. Wyrozumska, Warszawa.

Zajadło J., 1982, "Godność jednostki w aktach międzynarodowej ochrony praw człowieka”, Ruch Prawniczy, Ekonomiczny i Socjologiczny 2(1989). 